\title{
XV
}

\section{FORMAÇÃO SOCIAL BRASILEIRA E RACISMO ESTRUTURAL: DEBATE SOBRE A CRIMINALIZAÇÃO DA CANNABIS MEDICINAL*}

Sálvia Karen

\section{INTRODUÇÃO}

A cannabis sativa ficou popularmente conhecida como maconha no Brasil, mas recebeu vários nomes ao longo do tempo: haxixe, cânhamo, diamba, fumo de negro, fumo d'Angola, erva do diabo, pito de pango, liamba, riamba, cânhamo-da-índia entre outros. Originária da Ásia Central, a cannabis sativa é considerada uma planta exótica. Dado o fato de não ser uma planta nativa do Brasil, há diversas hipóteses sobre a chegada da planta, dentre elas temos a de que a maconha foi trazida pelos negros africanos escravizados e por esse motivo denominada Fumo de Angola. (CARLINI, 2006). Na África, além do uso medicinal, a maconha é considerada uma erva sagrada, fazendo parte de alguns rituais religiosos. No Brasil, o seu uso ritualístico-religioso pôde ser percebido em algumas cerimônias das religiões afro-brasileiras, umbanda e candomblé, no entanto, por conta da proibição e intolerância religiosa, poucos estudos relatam sobre esse uso (MACRAE; SIMÕES, 2000).

A partir de discursos morais, racistas e tendo como referência a política de restrição às drogas dos Estados Unidos, a primeira lei brasileira que proibiu o uso da maconha é datada de 1830. Cabe destacar que, apesar da proibição ser direcionada para todos, havia distinção de penas entre brancos e negros, evidenciando que a criminalização da maconha apresenta um caráter racista.

Conforme diversos estudos apontam, a sua aplicação medicinal é milenar, ou seja, a maconha nem sempre foi proibida, tendo sido utilizada no tratamento de uma gama de doenças, dentre elas malária, insônia, asma e epilepsia. $\mathrm{Na}$ contemporaneidade, os canabinóides ${ }^{1}$ presentes na planta cannabis sativa têm sido utilizados no tratamento do Mal de Alzheimer, Câncer, Fibromialgia, Mal

\footnotetext{
*DOI - 10.29388/978-65-86678-36-9-0-f-283-300

${ }^{1}$ Canabinóide é um termo utilizado para descrever as substâncias presentes na planta cannabis sativa que ativam os receptores do tipo CB1 ou CB2.
} 
de Parkinson, Dores Crônicas e Epilepsia Refratária. Considerado o Polígono da Maconha, o Nordeste brasileiro foi avaliado como o mais propício para a plantação e cultivo. Porém, apesar de todas as comprovações científicas dos efeitos medicinais positivos dos canabinóides, o plantio e cultivo de maconha no Brasil, para uso medicinal, é expressamente proibido pela Lei nº11.343/2006 (BRASIL, 2006), também conhecida como "Lei de Drogas".

Atualmente para conseguir medicamentos à base de cannabis sativa é preciso importá-los dos Estados Unidos ou da Europa, e só pode ser adquirido com a apresentação de um receituário médico com o Código Internacional de Doenças (CID) e a autorização da Agência Nacional de Vigilância Sanitária (ANVISA).

Isto posto, o que podemos perceber é que a proibição racista do uso da maconha no Brasil além de constituir enorme empecilho para a melhoria da qualidade de vida dos pacientes, se funda em uma associação do racismo estrutural aos interesses da indústria farmacêutica internacional, isto é, imperialismo e capitalismo dependente compondo duas faces de um mesmo projeto de dominação burguesa.

Os ideais de "modernidade" e "progresso", construídos por uma elite branca, patriarcal e cristã, destituiu a sabedoria popular dos povos originários, criminalizando suas práticas médicas e religiosas e exterminando-os. A história oficial é a história dos "vencedores", assim, analisaremos nesse capítulo, a formação social brasileira sob a perspectiva dos "vencidos", isto é, os "de baixo", segundo Florestan Fernandes, considerando o racismo como elemento estruturante que atravessa essa formação social e desembocou na criminalização da maconha.

\section{RACISMO E CRIMINALIZAÇÃO DA MACONHA NO BRASIL}

A criminalização da maconha no Brasil, atravessa vários aspectos, sociais, econômicos e ideo-políticos, pois a mesma se constitui como um traço do racismo estrutural, sendo esse um elemento dinâmico no desenvolvimento do capitalismo brasileiro, associado a composição de interesses econômicos da indústria farmacêutica internacional na comercialização de medicamentos à base de cannabis sativa.

A colonização brasileira é marcada por uma complexa e dialética dinâmica que mescla os movimentos internos da economia e os dinamismos do mercado mundial, relações que no Brasil se deram em caráter de dependência 
(FERNANDES, 2005). A escravidão deixou marcas na cultura, nos valores, nas relações pessoais e de produção que tem reflexos na contemporaneidade.

$\mathrm{Na}$ formação social brasileira, o autoritarismo e o racismo sublinham a política, a economia, o aparato repressivo do Estado e embasaram o pensamento social brasileiro. Alguns autores como Silvio Romero, Nina Rodrigues, Joaquim Nabuco e Oliveira Viana imbuídos das ideias que floresciam na Europa e nos Estados Unidos no final do século XIX, propuseram o "branqueamento" da sociedade como passagem para a "modernidade", pautados na ideia de que o "sangue branco" se sobrepunha a qualquer outro.

Os objetivos do capitalismo estão ligados à propriedade privada, acumulação de capital, superexploração da força de trabalho e a busca pelo lucro e pela concentração de riqueza, prestígio social e poder que implicam na captura da subjetividade dos "de baixo". (FERNANDES, 1975). Assim, o processo de modernização custou a vida de muitos trabalhadores, perpassando pela destruição da memória de negros e indígenas até o seu extermínio, em uma tentativa de destruir o saber popular, da noção de viver em comunidade, nos afastando da nossa ancestralidade, tudo em nome do "desenvolvimento". Portanto, exploração econômica e dominação ideológica constituem duas faces do projeto burguês de sociabilidade.

A Europa, o epicentro da tal modernidade, no qual o colonialismo foi condição indispensável para a formação da mesma, a colonialidade do poder colocou a raça e o racismo como princípios organizadores da acumulação do capital. Para Mignolo (2017), a modernidade não é um período histórico e sim a autonarração de atores e instituições que, a partir do Renascimento, conceberam-se a si mesmos como o centro do mundo.

Walter Benjamim (1938, apud LÖWY, 2005), no texto 'Aviso de Incêndio', analisado por Michael Löwy, faz uma crítica ao ideal de "modernidade", analisando as Teses sobre o Conceito de História, na qual Benjamin vê a neces sidade de compreender a história não do "ponto de vista dos vencedores" e sim "do ponto de vista dos vencidos", das classes oprimidas, mulheres, indígenas e negros. A partir das análises de Walter Benjamin (1938 apud LÖWY, 2005) é necessário compreender a história não do "ponto de vista dos vencedores" e sim "do ponto de vista dos vencidos", das classes oprimidas, mulheres, indígenas e negros. É imperativo "escovar a História a contrapelo", ou seja, ir contra a versão oficial da História, lutar contra a corrente, permitindo, assim, que os

\footnotetext{
${ }^{2}$ Para Florestan Fernandes “os de baixo” são os pertencentes às classes sociais subordinadas.
} 
verdadeiros heróis dos povos sejam conhecidos e homenageados. (BENJAMIM, 1938, apud LÖWY, 2005)

Conforme Benjamim (apud LÖWY, 2005), a cultura não existiria sem o trabalho anônimo dos excluídos, pois os tesouros culturais são construídos através da superexploração da força de trabalho daqueles que são marginalizados pelo sistema, isto é, os monumentos, esculturas que representam os "heróis" elegidos pela classe dominante, são na verdade "documentos da barbárie", erigidos pelo genocídio da classe trabalhadora.

Dito isso, quando analisamos o Brasil a partir da perspectiva dos "de baixo" (FERNANDES, 1975), identificamos que se trata de um país de capitalismo dependente, que é uma forma periférica e dependente do capitalismo monopolista, associando as formas nacionais e internacionais do capital financeiro, e tem o racismo como elemento estruturante que abarca todo o sistema, isto é, o Estado brasileiro se forja de forma a permitir e perpetuar o racismo como garantia de manutenção da classe dominante no poder, como examinado nos capítulos anteriores.

Ainda que o Brasil tenha sido o último país da América Latina a abolir a escravidão, o racismo não deve ser visto como mera herança escravocrata, pois ele estrutura as relações sociais no capitalismo brasileiro e revitaliza-se em elementos dinâmicos trazidos para a contemporaneidade. Por ser um elemento estruturante, o que observamos é que nunca houve um real rompimento com a ordem social escravocrata, mas a manutenção do racismo no contorno das relações sociais e de produção.

Podemos dizer que o racismo é uma forma sistemática de discriminação que tem a raça como fundamento, e que se manifesta por meio de práticas conscientes ou inconscientes que culminam em desvantagens ou privilégios para indivíduos, a depender do grupo racial ao qual pertençam (ALMEIDA, 2015, p. 25).

Para Almeida (2015), o termo raça é um fenômeno da modernidade, que remonta a meados do século XVI, sendo assim, a história da raça é a história da constituição política e econômica das sociedades contemporâneas. A expansão burguesa e a consequente cultura renascentista impuseram o europeu como homem universal e, consequentemente, os outros homens passaram a ser vistos como "versões" menos evoluídas do ser humano. Essa busca incessante em levar "civilização", "modernidade" e "liberdade" as organizações sociais consideradas "primitivas", desembocou no colonialismo, ainda que, para isso, também houvesse mortes e expropriações. 
Ora, é nesse contexto que a raça emerge como um conceito central para que a aparente contradição entre a universalidade da razão e do legado iluminista, o ciclo de morte e destruição do colonialismo e na escravidão possam operar simultaneamente como os fundamentos irremovíveis da sociedade contemporânea (ALMEIDA, 2015, p. 22).

A classificação pela raça surge então como justificativa para o extermínio das raças consideradas 'inferiores', como aconteceu com negros e indígenas que foram comparados a animais, recebendo os mais diversos "adjetivos": exóticos, bestiais, primitivos, selvagens.

Longe de ser um ato de piedade da Princesa Isabel como romanticamente se diz, a "abolição" da escravidão deve ser encarada como desdobramento das lutas anti-escravocratas que faziam pressões através de rebeliões e insurreições, e que teve adesão de alguns setores da classe média e profissionais liberais da época. Essas revoltas mostram que, negros e indígenas não eram os sujeitos submissos, tal como descrito nos livros de história, tendo participado efetivamente do processo de abolição da escravidão. Fernandes (2008, p. 30) evidencia o caráter revolucionário dos escravizados no processo abolicionista.

De um lado, a revolução abolicionista, apesar de seu sentido e conteúdo humanitários, fermentou, amadureceu e eclodiu como um processo histórico de condenação do "antigo regime" em termos de interesses econômicos, valores sociais e ideais políticos da "raça dominante". A participação do negro no processo revolucionário chegou a ser atuante, intensa e decisiva, principalmente a partir da fase em que a luta contra a escravidão assumiu feição especificamente abolicionistas. Mas, pela própria natureza da sua condição, não passava de uma espécie de aríete, usado como massa de percussão pelos brancos que combatiam o "antigo regime".

Conforme Clóvis Moura (1993), para a elite branca havia um lado negativo da escravidão, que eram as revoltas e insurreições. Dessa forma,

O Negro, durante a escravidão, lutou como escravo por objetivos próprios. Mas lutou, também, em movimentos organizados por outros segmentos sociais e políticos. A sua condição de escravo, porém, levava a que - mesmo nesses movimentos - ele não fosse aproveitado politicamente. Após a Abolição o mesmo acontece. O Negro, ex-escravo, é acionado em movimentos de mudança social e política, participa desses movimentos, mas é preterido, alijado pelas suas lideranças após a vitória dos mesmos (MOURA, 1993, p. 125). 
Durante a segunda metade do século XVIII, os portugueses criaram o Diretório dos Índios $^{3}$ que foi responsável por várias intervenções nos hábitos indígenas como a miscigenação através dos casamentos interétnicos, trabalho regular e ensino da língua portuguesa, no que eles reagiram.

Entretanto, os povos indígenas não ficaram apáticos às pretensões metropolitanas, suas ações, reações e manifestações foram diversas no mundo colonial, agiram conforme a necessidade surgida em seu cotidiano: fugindo, guerreando, negociando, adaptando-se, entre outras. Fixando-se nas vilas, não ficaram inertes à demanda colonial. Ao depararem com algum abuso cometido por colonos sobre si ou suas famílias, ou quando percebiam que a condição de livres que lhes fora impetrada pela legislação vigente não estava sendo respeitada, desenvolveram estratégias na tentativa de mudar aquele panorama (SANTOS, 2018, p. 83).

Verifica-se nessas passagens que, mesmo negros e indígenas tendo participado ativamente dos movimentos abolicionistas em prol de sua liberdade e em busca dos seus direitos, eles eram denegados pela classe dominante branca, que agia conforme os seus interesses, excluindo-os de qualquer possibilidade de emancipação.

Por conseguinte, ainda que fornecendo ingredientes políticos para o movimento, apesar de que todas as formas assumidas pelas tensões sociais, expressas no comportamento do escravo, propiciaram o substrato social para a ação dos abolicionistas, é inegável que a atuação daquele não teve nem pode adquirir imediatamente caráter político. Nota-se, contudo, que não teve, mas assumiu configuração política. Por intermédios de homens livres que organizam ou lideram o abolicionismo, o comportamento do cativo acaba adquirindo uma significação política notável (MOURA, 1990, p. 15).

Com as fugas e rebeliões dos escravizados e a assinatura da Lei Áurea, juridicamente deu-se "fim" à escravidão no Brasil, o que não significa que na prática ela tenha acabado e que a situação do povo negro e indígena tenha me lhorado, muito pelo contrário. A Abolição da Escravidão em 1888 e a Proclamação da República em 1889, só teoricamente colocaram negros e indígenas como "livres" e "cidadãos", pois nem as leis emancipacionistas os preparou para a sociedade de classes, nem houve "democracia" para eles.

\footnotetext{
${ }^{3}$ Diretório dos Índios foi uma lei elaborada em 1755, e tornada pública em 1757, por D. José I, rei de Portugal, através de seu ministro, o Marquês de Pombal, que dispunha regras sobre os aldeamentos indígenas, administradas por um diretor.
} 
A proibição do tráfico negreiro através de leis que extinguiam a mão de obra escravizada, acabou gerando uma crise no sistema de produção: era preciso força de trabalho qualificada para a nova ordem social. Ao povo negro não foi dada nenhuma qualificação para o processo de industrialização, assim a vinda do imigrante branco como mão-de-obra "adequada" se ajustou perfeitamente ao desejo das elites de "embranquecer" a sociedade brasileira. A importação da mão de obra do imigrante branco acabou substituindo a mão de obra de negros e indígenas escravizados, lançando-os a situações degradantes, sem oportunidades de inserção.

Logo se descobriu que a imigração punha à disposição dos fazendeiros e do crescimento econômico urbano outro tipo de reserva de mão de obra, a custos baixos. As leis emancipacionistas golpearam ainda mais o modo de produção escravista e fortaleceram as duas preocupações, a da preparação do negro para o trabalho livre e da importação de imigrantes, como mão de obra barata. Por fim, prevaleceu a última tendência (FERNANDES, 2017, p. 38).

Assim, a modernização e urbanização ocorridas no final do século XIX e início do século XX colocaram o negro em uma posição ainda mais desfavorável e desigual, sem preparo para o trabalho livre ele teve como principal concorrente o imigrante branco, o que dificultou ainda mais a sua inserção na nova ordem social.

Conforme os estudos realizados pelos sociólogos Florestan Fernandes e Roger Bastide sobre a situação do negro na cidade de São Paulo, identifica-se que no período pós-abolição, as oportunidades ofertadas aos escravizados não eram em nada vantajosas, nos lugares onde ainda era próspera a agricultura do café, a realidade dos escravos libertos eram as seguintes:

[...] os ex-escravos tinham de optar, na quase totalidade, entre a reabsorção no sistema de produção, em condições substancialmente análogas às anteriores, e a degradação de sua situação econômica, incorporando-se a massa de desocupados e de semi-ocupados da economia de subsistência do lugar ou de outra região (FERNANDES, 2008, p. 35).

Até mesmo nos lugares onde a produção gerava altos lucros influenciando nos padrões econômicos e na organização do trabalho, os ex-escravizados tinham que concorrer ou com um exército de reserva mantido fora das atividades produtivas ou com a mão de obra europeia que se mostrava mais "adaptada" ao novo regime de trabalho livre. Nenhuma dessas condições proporciona- 
va ao ex-escravizado oportunidade real e digna de inserção na nova ordem social competitiva, colocando os em desvantagem em relação aos imigrantes.

O trabalho livre não contou como uma fonte de libertação do homem e da mulher negros: ele os coloca em competição com os imigrantes em condições desiguais. Os empregadores consideravam os "trabalhadores livres" recém-chegados uma opção melhor, mais racional e compensadora! (FERNANDES, 2017, p. 39).

Dessa forma, não houve nenhum movimento de preparação para o exescravizado, assim, os negros estavam "livres", porém, foram jogados para as franjas da sociedade, sem trabalho e sem meios de prover a sua própria subsistência, o que acirrou a desigualdade não só social, mas principalmente racial, entre negros e brancos no Brasil. O processo de industrialização resultou para negros e indígenas o subemprego e a pobreza.

A escravidão se esboroou, mas o substituto e o sucessor do escravo não foi o trabalhador negro livre, mas o trabalhador branco livre estrangeiro ou então o homem pobre livre, mestiço ou branco, porém sempre marginalizado sob o regime de produção escravista (FERNANDES, 2017, p. 38).

O que restou para os escravizados, "livres", no entanto, nem sempre assalariados, foi morar em lugares precários, subúrbios, contando com os piores empregos e mais baixos salários. Em suma, o racismo estrutura o capitalismo dependente e a manutenção dos "condenados do sistema" se faz retirando até mesmo a possibilidade de venda da sua força de trabalho, e, quando há a possibilidade, esta se dá de forma bem precária, análoga à escravidão. Assim, as desigualdades são funcionais para a lógica de produção e reprodução do capitalismo, na medida que se tem uma força de trabalho mais desvalorizada, como no caso dos homens negros e na pior situação, as mulheres negras, explicitando que a expropriação se constitui como forma do capitalismo existir e se reproduzir.

O homem negro, no entanto, foi peneirado ou selecionado negativamente. Empurrado para a franja dos piores trabalhos e de mais baixa remuneração, ele se sentiu, subjetivamente, como se ainda estivesse condenado à escravidão (FERNANDES, 2017, p. 39).

\footnotetext{
${ }^{4}$ Para Florestan Fernandes os "condenados do sistema" são os indivíduos impelidos a viver a margem da sociedade devido às desigualdades inerentes ao sistema capitalista.
} 
Fernandes (2008) ressalta a diferença de gênero: para o homem foi ofertado os "trabalhos sujos", "arriscados"; já a mulher negra, mantinha a posição de doméstica, ora trabalhando nos afazeres domésticos, ora satisfazendo os desejos sexuais do patrão, corroborando com Gonzales (1984) quando diz que à mulher negra foi dado o "papel" de "objeto sexual", de "mulata do carnaval", "ama-de-leite", de criar os filhos dos brancos enquanto os seus estavam sendo criados sozinhos.

Como todo mito, o da democracia racial oculta algo para além daquilo que mostra. Numa primeira aproximação, constatamos que exerce sua violência simbólica de maneira especial sobre a mulher negra. Pois o outro lado do endeusamento carnavalesco ocorre no cotidiano dessa mulher, no momento em que ela se transfigura na empregada doméstica. É por aí que a culpabilidade engendrada pelo seu endeusamento se exerce com fortes cargas de agressividade. É por aí, também, que se constata que os termos mulata e doméstica são atribuições de um mesmo sujeito. A nomeação vai depender da situação em que somos vistas (GONZALES, 1984, p. 228).

O mito da democracia racial por muito tempo embasou a tese de que no Brasil, negros, brancos, indígenas e tantas outras raças conviviam harmonicamente. Essa teoria foi endossada por algumas obras escritas no século XX, como a famigerada obra de Gilberto Freyre, Casa Grande-Senzala, escrito em 1933 ,

[...] Gilberto Freyre antecipava-se na elaboração de uma interpretação social do Brasil através das categorias casa-grande e senzala, colocando a nossa escravidão como composta de senhores bondosos e escravos submissos, empaticamente harmônicos, desfazendo, com isso, a possibilidade de se ver o período no qual perdurou o escravismo entre nós como cheio de contradições agudas, sendo que a primeira e mais importante e que determinava todas as outras era a que existia entre senhores e escravos (MOURA, 2019, p. 40, grifos do autor).

Esse mito foi utilizado pelas elites, no intuito de esconder a realidade brasileira que foi construída com base na desigualdade não só econômica e social, mas principalmente racial, pois a manutenção das estruturas coloniais que remetem à escravidão, tinha como objetivo continuar garantindo riqueza, prestígio social e poder à classe dominante.

Os fatos- e não as hipóteses - confirmam que o mito da democracia racial continua a retardar as mudanças estruturais. As elites, que se apegaram 
a ele numa fase confusa, incerta e complexa de transição do escravismo para o trabalho livre, continuam a usá-lo como expediente para "tapar o sol com a peneira’ e de autocomplacência valorativa. Pois, consideremos: o mito - não os fatos - permite ignorar a enormidade da preservação de desigualdades tão extremas e desumanas, como são as desigualdades raciais no Brasil (FERNANDES, 2017, p. 33-34).

De tal modo, o negro teve um lugar social estabelecido com base na hierarquização por sexo e raça, para a autora Lélia Gonzalez (1984), o mito da democracia racial criou o racismo por denegação no Brasil, o qual a existência é negada apesar de ser uma realidade, impedindo a consciência objetiva do racismo e suas práticas cruéis.

Para a massa da população negra a questão é ainda mais grave que para suas elites. Ela se vê expulsa da sociedade civil, marginalizada e excluída. E defronta-se com o peso de um bloqueio insuperável e de uma forma de dominação racial hipócrita, extremamente cruel e camuflada, que aumenta a exploração do negro, anula suas oportunidades sociais, mas, ao mesmo tempo, identifica o Brasil como um país no qual reina a harmonia e igualdade entre as raças. A armadilha faz a cabeça do negro, que se desorienta e com frequência acaba capitulando, como se ele fosse responsável pelos "seus fracassos (FERNANDES, 2017, p. 40).

Desta feita, o que podemos perceber é que o racismo é um elemento estrutural das relações sociais e de produção do desenvolvimento do capitalis mo no Brasil. Isso porque a formação social brasileira, não se deu de forma tradicional, pois não houve uma Revolução Burguesa Clássica, já que não vivemos o feudalismo, como na Europa, por exemplo. O capitalismo no Brasil se deu pela via não clássica ${ }^{5}$, se forjando, de acordo com Fernandes (2005) pelos padrões compósito de hegemonia burguesa e padrão dual de expropriação do excedente econômico, ou seja, houve uma superexploração da força de trabalho que alimentava tanto a economia interna, como a externa e a burguesia local conciliando os seus interesses com o imperialismo.

A convergência de interesses burgueses internos e externos fazia da dominação burguesa uma fonte de estabilidade econômica e política, sendo esta vista como um componente essencial para o tipo de crescimento econômico, que ambos pretendiam, e para o estilo de vida política posta em prática pelas elites (e que servia de suporte ao padrão vigente de estabilidade econômica e política). Portanto, a dominação burguesa se associava a procedimentos autocráticos, herdados do passado ou improvisa-

\footnotetext{
${ }^{5}$ Ver capítulo 2 desse livro para melhor entendimento sobre a Revolução Burguesa no Brasil.
} 
dos no presente, e era quase neutra para a formação e a difusão de procedimentos democráticos alternativos, que deveriam ser instituídos (na verdade, eles tinham existência legal ou formal, mas eram socialmente inoperantes) (FERNANDES, 2005, p. 243).

Isto é, houve uma conciliação entre a burguesia e as oligarquias agrárias voltada para atender as demandas dos países de capitalismo central, o que configurou o Brasil como país de capitalismo dependente. Como não houve ruptura entre a formação social colonial escravista e o sistema capitalista vindouro, ocorreu um processo de arcaização do moderno e modernização do arcaico, ou seja, a chegada de um sistema não extinguiu algumas características econômicas, políticas e ideo-culturais do sistema anterior (FERNANDES, 2005).

Dessa forma, a constituição da burguesia brasileira se forjou em um estado de heteronomia econômica e cultural, de característica dependente e com a menor margem de autonomia possível em relação aos países imperialistas. Assim, a burguesia brasileira emerge com fortes traços do regime colonial, subordinada aos países de capitalismo avançado, contando com uma democracia apenas para a classe dominante.

Considerando que a revolução burguesa envolve rupturas que não foram realizadas pela burguesia brasileira o que observamos é que, o desenvolvimento das relações sociais fora dissociado da democracia de participação ampliada em detrimento de uma democracia restrita. Desta feita, no Brasil, "[...] não se trata de "restaurar a democracia, mas de instaurar a democracia", afirma Fernandes (1980, p. 30).

A vista disso, apesar de viver em uma ordem social competitiva e arfar pela modernização e pelo "desenvolvimento", a mentalidade da burguesia brasileira ainda era (e ainda é) a do senhor rural: uma burguesia plutocrática ${ }^{6}$ que exaltava a propriedade privada, fazendo com que a oligarquia cafeeira se trans formasse na classe burguesa, operando o processo que Fernandes (1975) identificou como o aburguesamento do "senhor rural".

Essa inserção subordinada e dependente do Brasil na ordem capitalista e imperialista implicou a sua adequação aos padrões de acumulação de capital, o que consequentemente intensificou a exploração e extração de mais-valor e precarizou as relações de trabalho. Tal processo instituiu uma forma política com determinações "pelo alto", um Estado forte (leia-se violento e repressor) se impondo a uma sociedade civil fraca. O Estado não tinha apenas uma forma autocrática, mas também um caráter autocrático, isto é,

${ }^{6}$ Plutocracia: sistema político no qual o poder é exercido pelo grupo mais rico. 
A burguesia brasileira estabeleceu uma associação mais íntima com o capitalismo financeiro, reprimiu com violência qualquer ameaça operária e transformou o Estado no seu instrumento. Assim, configurou uma "dominação heterogênea e compósita" que não rompeu com a dependência e reorganizou o padrão de dominação externa, fazendo com que "o passado se repita no presente" pelo caráter "autocrático e opressivo da dominação burguesa” (FERNANDES, 2005, p. 255).

O caráter autocrático, opressivo e racista do capitalismo brasileiro pode ser verificado nos valores e ideologias das elites nativas do poder (oligarquia) e o pensar e agir fundamentados na mentalidade capitalista, ou seja, repressão aos movimentos organizados pela classe trabalhadora e de "[...] democracia para os mais iguais" (FERNANDES, 2019, p. 61).

Esse autoritarismo marcante nas relações de dominação no capitalismo dependente, aniquila as possibilidades de uma "revolução contra a ordem" ${ }^{7}$ " e apresenta o mínimo possível de ações constitutivas da "revolução dentro da ordem ${ }^{8 ",}$, tendo como características o uso da violência e uma democracia restrita, ou seja, a repressão é imposta, entre outras, pela militarização do Estado, excluindo qualquer possibilidade de aspiração democrática.

A questão da democracia começa por ser um desafio a desobediência civil sistemática e generalizada, gerando no presente a negação da ditadura de minorias poderosas e sua substituição por uma democracia organizada pela e para a maioria, pois não poderá haver democracia em outras condições. (FERNANDES, 1980, P. 129).

Assim, o termo "Democracia" no Brasil é traçado de forma a permitir que "os de baixo" não tenham qualquer possibilidade de participação política, ressaltando que raça e classe estão imbricadas nesse processo, e que o Estado utiliza o seu aparato ideológico para acentuar as desigualdades raciais e sociais. As classes subalternadas passam a temer a coerção do Estado, uma vez que o uso do aparato repressivo não deixa para a classe trabalhadora nem os direitos fundamentais.

O período da Primeira República no Brasil que compreende os anos de 1889 a 1930 foi marcada pelo uso da coerção do Estado. As expressões da

\footnotetext{
${ }^{7}$ Revolução contra a ordem: No sentido do socialismo e contra o capitalismo e a ordem burguesa, transformando de forma estrutural a sociedade capitalista. (FERNANDES, 1975).

${ }^{8}$ Revolução dentro da ordem: dentro dos marcos das relações capitalistas, possibilitando uma ampliação da participação política da classe trabalhadora com objetivo de superar a ordem burguesa. (FERNANDES, 1975).
} 
"questão social" eram vistas como "caso de polícia" para garantir a hegemonia da classe que detinha o poder econômico e político. Assim, o período pós-abolição foi marcado por lançar a mão de obra escrava no mercado de trabalho livre que estava em formação, o que fez aumentar o número de desempregados e subempregados. Esses trabalhadores expropriados de suas terras, a maioria expulsos das fazendas de café, foram morar nos grandes centros, habitando cortiços, moradias insalubres e precárias.

Como forma de resistência e reivindicando melhores condições de vida, nesse mesmo período tiveram início as primeiras formas de organização da classe operária no final do século XIX, tendo ocorridos dois importantes Congressos, o primeiro, Congresso Socialista Brasileiro em 1892 e em 1906, o primeiro Congresso Operário Brasileiro. O Brasil passava por uma transformação rumo a industrialização e modernização, dessa forma, a nova ideologia do trabalho vinha acompanhada de vigilância e repressão por parte do Estado, exercidos por autoridades policiais e judiciárias, com o intuito de moldar a força de trabalho às exigências do capital.

Era necessário que o conceito de trabalho ganhasse uma valoração positiva, articulando-se então com conceitos vizinhos como os de "ordem" e "progresso" para impulsionar o país no sentido do "novo", da "civilização", isto é, no sentido da constituição de uma ordem social burguesa. O conceito de trabalho se erige, então, no princípio regulador da sociedade, conceito este que aos poucos se reveste de roupagem dignificadora e civilizadora (CHALHOUB, 2001, p. 48).

No entanto, esse controle era percebido não só com relação ao trabalho, mas também no que tange aos momentos e lugares de sociabilidade desses indivíduos. Conforme indica Mattos (2008), esse processo atingiu também os espaços de sociabilidade e moradia da classe operária, incidindo sobre os padrões de conduta familiar e social.

Chalhoub (2001), afirma que, aqueles que não possuíam trabalho e apresentavam algum comportamento interpretado pelas elites como rebeldia, foram estigmatizados como sendo a "classe perigosa", "vadios", "promíscuos", indivíduos que precisavam ser corrigidos através do encarceramento para se transformarem em trabalhadores. Qualquer ameaça de oposição da classe traba-

\footnotetext{
${ }^{9}$ Questão Social [...] não é senão as expressões do processo de formação e desenvolvimento da classe operária e de seu ingresso no cenário político da sociedade exigindo seu reconhecimento como classe por parte do empresariado e do Estado. É a manifestação, no cotidiano da vida social, da contradição entre o proletariado e a burguesia, a qual passa a exigir outros tipos de intervenção mais além da caridade e repressão (IAMAMOTO; CARVALHO, 1995, p. 77).
} 
lhadora aos interesses hegemônicos era enfrentada com repressão, a frase "questão social como caso de polícia", dita pelo então Presidente da República Washington Luís, sintetiza o pensar e agir do Estado.

No Brasil, o debate sobre classe não pode estar dissociado do debate de raças. Os que foram considerados "vadios", "classe perigosa" eram em sua esmagadora maioria, negros, que desde os tempos da escravidão não tiveram oportunidades de trabalho dignas, procurando meios alternativos de sobrevivência. Nas palavras de Florestan (2017, p. 84) “[...] esse dilema liga entre si luta de classes e luta de raças (uma não esgota a outra e, tampouco, uma não se es gota na outra)".

A criminalização da maconha, vista como hábito funesto da raça negra, se enquadra justamente na concepção que a elite branca, patriarcal e cristã tinha de que, os valores culturais oriundos de negros e indígenas, considerados 'inferiores', não poderiam ser aceitos na República vindoura, pois poderiam "atrapalhar" o desenvolvimento do capitalismo, sendo os "condenados do sistema" duramente perseguidos e exterminados. A estreita ligação da maconha com os negros e com a suposta "vadiagem" causada pelo consumo da planta, fez surgir o ditado racista na época que dizia: "maconha em pito faz negro sem vergonha" (SAAD, 2015).

Dessa forma, antes mesmo da instituição da República, o Brasil já era pioneiro na criminalização da cannabis sativa, criando, em 1830, no Código de Posturas da Câmara Municipal do Rio de Janeiro, a primeira lei que proibia o seu uso, diferenciando as penas para brancos e negros, o que demonstra o caráter racista da criminalização. Cem anos depois a planta é incluída na lista de substâncias proibidas, o que levou a uma legislação proibitiva mais abrangente em 1932.

O autoritarismo e o abuso de poder com relação aos negros era a regra, dessa forma, o Código Penal de $1890^{10}$ trazia o título "Dos vadios e capoeiras" em seu Capítulo XIII e na mesma época houve a criação da delegacia "Seção de Entorpecentes Tóxicos e Mistificação", ambos com o objetivo de punir e controlar os hábitos da população negra. Essa delegacia tinha como objetivo combater as práticas de cultos de matriz africana, umbanda e candomblé, consideradas pela elite branca como "baixo espiritismo" e a maconha utilizada nesses rituais, incluindo a restrição ao samba e a capoeira, como forma de apagar e reprimir a cultura afro e indígena.

${ }^{10}$ Decreto no 847 de 11 de outubro de 1890. 
A criação da Inspetoria de Entorpecentes e Mistificações, denunciava: o setor responsável por perseguir as religiões era o mesmo para reprimir o comércio e consumo de tóxicos. A Inspetoria representava a repressão conjunta de tudo que pudesse levar à "loucura", à "alienação", à "doença mental" e ao "crime". A associação entre magia e loucura era absolutamente comum pois reinava a ideia de que o meio era promíscuo: o local, as pessoas, a música, a dança, tudo era favorável à degeneração mental. (SAAD, 2015, p. 121).

A proibição racista da maconha trazida para a contemporaneidade limita e exclui possibilidades de pesquisas sobre o uso medicinal da cannabis no Brasil, e concomitantemente favorece a lucratividade das indústrias farmacêuticas internacionais movimentando um mercado bilionário nos Estados Unidos e Canadá, inclusive com fundos de investimento e aplicação na bolsa de valores, pois a maconha é uma nova commodity ${ }^{11}$.

Enquanto a planta continua proibida e o acesso aos medicamentos é caro e burocrático, famílias e associações lutam na justiça pelo direito ao autocultivo para que as associações consigam fornecer aos pacientes um produto artesanal de qualidade com custo reduzido. De tal modo, duas associações brasileiras conseguiram a liminar na justiça para a fabricação do óleo artesanal e outros produtos à base de cannabis, são elas a Associação Brasileira de Apoio Cannabis Esperança (ABRACE ESPERANÇA), associação sem fins lucrativos que está localizada na cidade de João Pessoa, na Paraíba; e a Apoio à Pesquisa e Pacientes de Cannabis Medicinal (APEPI), localizada na cidade do Rio de Janeiro. A reivindicação dos pacientes e associações é pela garantia dos direitos individuais e a luta pelo autocultivo, que vai contra a lucratividade da indústria farmacêutica.

\section{CONSIDERAÇÕES FINAIS}

Em síntese, a dupla articulação do desenvolvimento do capitalismo no Brasil e o caráter autocrático da burguesia excluiu da Nação a maioria dos despossuídos, sacrificando a universalização dos direitos, até mesmo os direitos fundamentais.

Tendo em vista que a regulamentação do acesso à cannabis medicinal no Brasil é alvo de disputa entre frações da própria burguesia, ela se torna uma questão de democracia, pois o direito à saúde é dever do Estado e a luta pela

${ }^{11}$ Commodity vem do inglês e originalmente tem significado de mercadoria. Dessa forma seu preço é determinado pelo mercado mundial como uma consequência da oferta e demanda. 
cannabis medicinal é uma luta antirracista pelo direito a vida e contra a mercantilização da saúde.

\section{REFERÊNCIAS}

ALMEIDA, S. O que é racismo estrutural? Belo Horizonte: Letramento, 2015.

BRASIL. Lei no 11.343 de 23 de agosto de 2006. Institui o Sistema Nacional de Políticas Públicas sobre Drogas- Sisnad. Presidência da República. Secretaria Geral. Subchefia para assuntos jurídicos. Disponível em: http://www.planalto.gov.br/ccivil_03/_Ato2004-2006/2006/Lei/L11343.htm. Acesso em 10 fev. 2020 .

. Decreto no 847 de 11 de outubro de 1890. Promulga o Código Penal. Presidência da República. Secretaria Geral. Subchefia para assuntos jurídicos. Disponível em: < http://www.planalto.gov.br/CCivil 03/decreto/18511899/D847.htm.> Acesso em 10 fev. 2020.

CARLINI, E. A. História da maconha no Brasil. Rio de Janeiro: Jornal Brasileiro de Psiquiatria. 2006. Disponível em: < https://www.scielo.br/scielo.php? script $=$ sci arttext\&pid $=$ S0047-20852006000400008 $>$. Acesso em: 10 fev. 2020.

CHALHOUB, S. Trabalho, Lar e Botequim: cotidiano dos trabalhadores no Rio de Janeiro da belle époque. São Paulo: Editora da UNICAMP, 2001.

FERNANDES, F. Capitalismo dependente e classes sociais na América Latina. Rio de Janeiro: Zahar Editores. 1975.

. Brasil: em compasso de espera. Pequenos escritos políticos. São Paulo: Editora Hucitec, 1980.

. Revolução Burguesa no Brasil: ensaio de interpretação sociológica. São Paulo: Globo, 2005.

. A integração do negro na sociedade de classes. (O legado da raça branca). v. I. São Paulo: Editora Globo, 2008. 
O Significado do Protesto Negro. São Paulo: Expressão Popular co-edição Editora da Fundação Perseu Abramo, 2017.

Apontamentos sobre a "Teoria do Autoritarismo". São Paulo: Expressão Popular, 2019.

GONZALEZ, L. Racismo e Sexismo na cultura brasileira. Revista Ciências Sociais Hoje. Anpocs, Rio de Janeiro, v.1, p. 223-244, out. 1984.

IAMAMOTO, M. V.; CARVALHO, R. Relações Sociais e Serviço Social no Brasil. Esboço de uma interpretação histórico/metodológica. São Paulo: Cortez/CELATS, 1995.

LOWY, M. Walter Benjamin. Aviso de Incêndio. Uma leitura das teses "Sobre o conceito de história". Trad. Wanda Nogueira Caldeira Brant. São Paulo: Boitempo, 2005.

MACRAE, E.; SIMÕES, J. A. Roda de fumo: o uso da maconha entre camadas médias urbanas. Salvador: Editora da Universidade Federal da Bahia. 2000. Disponível em: $<$ https://repositorio.ufba.br/ri/bitstream/ri/4702/1/Rodas \%20de\%20fumo.pdf>. Acesso em: 11 fev. 2020.

MATTOS, Marcelo Badaró. Escravizados e Livres: experiências comuns na formação da classe trabalhadora carioca. Rio de Janeiro: Bom Texto, 2008.

MIGNOLO, Walter. Desafios decoloniais hoje. Foz do Iguaçu: Epistemologias do Sul. 2017. Disponível em: <https://revistas.unila.edu.br/epistemologiasdosul/article/view/772/645>. Acesso em: 20 maio 2020.

MOURA, C. Rebeliões da Senzala: A questão social no Brasil. São Paulo: Lech Livraria Editora Ciências Humanas Ltda. 3. ed. 1990.

. História do negro brasileiro. São Paulo: Perspectiva, 1993.

. Sociologia do Negro Brasileiro. São Paulo: Perspectiva, 2019. 
SAAD, L. G. "Fumo de Negro": A criminalização da maconha no Brasil. (c.1890-1932). Salvador: Editora da Universidade Federal da Bahia. 2015. Disponível em: <file:///C:/Users/salvi/OneDrive/Área\%20de\%20Trabalho/ Dissertação/DISSERTAC̄̃̃O\%20LUISA\%20SAAD.pdf>. Acesso em: 20 jul. 2020.

SANTOS, R. R. N. dos. "Diz o índio...” Políticas Indígenas no Vale Amazônico. (1777-1798). Jundiaí: Paco Editorial, 2018. 